\title{
Control of The Spread of TB-HIV/AIDS Coinfection Using Optimal Control
}

\author{
Yuyun Monita ${ }^{1 *}$, Putroue Keumala Intan ${ }^{2}$ \\ ${ }^{1,2}$ Department of Mathematics, UIN Sunan Ampel Surabaya, Indonesia
}

\section{Article history: \\ Received Nov 24, 2020 \\ Revised May 25, 2021 \\ Accepted Jun 30, 2021}

Kata Kunci:

Koinfeksi TB-HIV/AIDS,

Pontryagin, Runge-

Kutta orde keempat.

Keywords:

TB-HIV/AIDS

coinfection, Pontryagin,

Fourth order Runge-

Kutta.

\begin{abstract}
Abstrak. Suatu keadaan dimana seorang individu terkena penyakit TB sekaligus HIV/AIDS di dalam tubuhnya dinamakan koinfeksi TB-HIV/AIDS. Penelitian ini bertujuan untuk meminimumkan populasi koinfeksi TB-HIV/AIDS dengan pengeluran biaya pengobatan yang minimum, hal tersebut berarti meminimumkan fungsi objektif $(J)$ atau fungsi tujuan. Pada penelitian ini dilakukan modifikasi model dengan penambahan populasi pengobatan untuk penderita HIV dengan ARV $\left(R_{H}\right)$. Jumlah populasi yang digunakan berjumlah 11 kelas dengan penggunaan tiga buah kontrol meliputi pengobatan untuk individu dengan TB laten $\left(u_{1}\right)$, TB aktif $\left(u_{2}\right)$, dan HIV $\left(u_{3}\right)$. Setelah dilakukan simulasi numerik menggunakan metode forward backward Runge-Kutta orde keempat diperoleh hasil bahwa skenario 7 menjadi skenario terbaik dalam mengendalikan penyebaran koinfeksi TB-HIV/AIDS karena menghasilkan nilai $J$ paling minimum yaitu sebesar 1401,44. Hal tersebut berarti dengan memberikan pengobatan pada individu dengan TB laten, TB aktif, dan HIV secara bersama-sama dapat mengurangi populasi koinfeksi TB-HIV/AIDS dengan biaya pengobatan yang minimum.
\end{abstract}

\begin{abstract}
The condition in which an individual is affected by TB and HIV/AIDS in his body is called a TB-HIV/AIDS coinfection. This research aims to minimize the populations of TB-HIV/AIDS coinfection with a minimum expenditure on medical expenses, that means minimizing the objective's function $(J)$ or purpose function. In this research, modification of the model was carried out by adding the treatment population for HIV patients with ARV $\left(R_{H}\right)$. The population used was 11 classes with the use of three controls including treatment for individuals with latent TB $\left(u_{1}\right)$, active TB $\left(u_{2}\right)$, and HIV $\left(u_{3}\right)$. After performing numerical simulation using the forward backward fourth order Runge-Kutta, the results show that scenario 7 is the best scenario in controlling the spread of TBHIV/AIDS coinfection because it resulted a minimum $J$ value of 1401,44 . This means that providing the treatment for individuals with latent TB, active TB, and HIV in tandem can reduce the populations of TB-HIV/AIDS coinfection in the minimum treatment cost.
\end{abstract}

\section{How to cite:}

Y. Monita and P. K. Intan, "Control of The Spread of TB-HIV/AIDS Coinfection using Optimal Control”, J. Mat. Mantik, vol. 7, no. 1, pp. 96-106, May 2021.

\section{CONTACT:}

Yuyun Monita, $\boldsymbol{\nabla}$ yuyunmonita@gmail.com 9 Department of Mathematics, UIN Sunan Ampel Surabaya, Surabaya, Jawa Timur 60234, Indonesia 


\section{Introduction}

AIDS (Acquired Immune Deficiency Syndrome) is an infectious disease in which the human immune system is decreased or damaged by HIV (Human Immunodeficiency Virus) infection. HIV will attack the immune system so that the body is unable to fight infections due to weak immunity [1]. The immunity of people with HIV/AIDS (ODHA) decreases because the number of Cluster Differential Four cells decreases. The Joint United Nations Programme on HIV and AIDS (UNAIDS) stated that in 2018 there were 37,9 million people in the world living with HIV, of which 640.000 occurred in Indonesia [2], [3]. ODHA are more likely to get Opportunistic Infection (OI), diseases that attacks a person because his immune system is weak [4], [5]. The spread of HIV in the body can be suppressed by performing Antiretroviral (ARV) Therapy (ART). ARV can inhibit the replication process of HIV in the body [1]. HIV/AIDS can be transmitted through sexual intercourse, blood, pre-ejaculation, vaginal fluids semen and by mothers to babies who are conceived or breastfed [6]. One-third of ODHA are infected with Tuberculosis (TB), even TB is the most common OI and the main cause of death in ODHA [7], [8].

TB is an infectious disease caused by the Mycobacterium tuberculosis (Mtb) or tubercle bacilli that can attack some parts of the body such as muscles, bones, joints and most commonly the lungs [9], [10]. In 2017 there were 10 million people in the world infected with TB, of which 420.000 occurred in Indonesia [8], [11]. The stage of TB disease starts from latent TB to active TB. The development of latent or exposed TB into active TB can occur at any time. People with latent TB have Mtb in their body but cannot transmit it to other people, while people with active TB are able to transmit it to other. TB transmission occurs through the air, namely when an active TB patient cough or sneeze, Mtb will come out of the lungs in the form of droplet nuclei that can last several hours in the air and cannot be seen with the naked eye. Treatment of latent TB has an important role in reducing the risk of latent TB developing into active TB [7], [9], [12]-[16].

TB-HIV coinfection is a condition in which an individual is infected by both Mtb and HIV [13]. When an individual is coinfected with TB-HIV, HIV is able to accelerate activation of TB and TB can increase the rate of progression from HIV to AIDS [17]. Therefore, an appropriate strategy is needed to control the spread of TB-HIV/AIDS coinfection. These efforts can be done by using mathematical modeling. Mathematical modeling has an important role in analyzing the control of a disease with optimal control [12]. In general, the optimal control problem is the same as the optimization, which is the process to get the best solution in a problem. Optimization in optimal control theory is a function that can optimize $(\mathrm{max} / \mathrm{min})$ performance index or objective function [18]. Objective function is a target that is to be achieved from an optimal control problem [19].

Several studies on controlling the spread of disease with optimal control have been carried out, among them Sukokarlinda [1] has analyzed controlling the spread of HIV by applying one control in the form of giving ARV drug. Gao and Huang [20] have analyzed the control for TB by giving the vaccine and two other treatments. Bhunu,et al [21] have analyzed and performed optimal control for the spread of TB-HIV/AIDS coinfection by using 10 populations and 3 types of controls in the form of treatment for individuals with latent TB $\tau_{1}$, active TB $\tau_{2}$, and AIDS $\alpha$, each with static or constant values.

Bhunu et al's research has been developed by several studies including Rayhan [13] and Tanvi and Aggarwal [22]. Rayhan uses dynamic control in the form of treatments for individuals with latent TB $u_{1}$, active TB $u_{2}$ and AIDS $u_{3}$, thereby causing changes in the rate of control over time. His research aims to minimize the number of people with TBHIV/AIDS infected. Based on these objectives, the objective function established only involves the infected TB-HIV/AIDS population. Meanwhile, Tanvi and Aggarwal added the AIDS treatment population so that the research involved 11 populations. The methods used in both studies are Pontryagin Minimum Principle for optimal control problems and Runge-Kutta (RK) namely fourth order Runge-Kutta (RK4) for numerical solutions. 
The RK4 is one of the most frequently used numerical methods for solving differential equation problems because of its small truncation errors, resulting in a good approximate solution [23]. This was supported by Subhashini and Srividhya [24] who stated that the RK method had a small error value in solving an equation. And Puspitasari, et al [25] stated that the RK4 method is better than The Adam-Bashfort Moulton method.

In this study, the authors will develop Rayhan's research by modifying the model for the spread of TB-HIV/AIDS coinfection in the form of increasing the class of the treatment population for individuals with $\operatorname{HIV}\left(R_{H}\right)$ using ARV so that the population to be used is 11 classes. This is done because ARV administration can be done when the people is infected with HIV. Giving ARV can reduce the spread of HIV because ARV can inhibit the replication process of HIV in the body so that it can reduce the progression of HIV to AIDS [1]. Furthermore, the objective function will be expanded by involving the TB-HIV/AIDS exposed population, so that the objective function to be used includes the exposed to and infected with TB-HIV/AIDS populations. This is in accordance with the aim of this study, namely to control the spread of TB-HIV/AIDS coinfection by reducing the number of TB-HIV/AIDS coinfection people, namely those TB-HIV exposed, TB-AIDS exposed, TB-HIV infected or TB-AIDS infected. And, there will also be addition trial scenarios aimed at obtain the most optimal strategy from the new model.

\section{TB-HIV/AIDS Coinfection Model}

The population used is 11 classes including population class of susceptible $S$, exposed to TB $E_{T}$, infected with TB $I_{T}$, recovered from TB $R_{T}$, infected with HIV $I_{H}$, infected with AIDS $I_{A}$, exposed to TB-HIV $E_{T H}$, exposed to TB-AIDS $E_{T A}$, infected with TB-HIV $I_{T H}$, infected with TB-AIDS $I_{T A}$, treatment of HIV $R_{H}$ as shown in Figure 1.

$$
\begin{aligned}
& \frac{d S}{d t}=\Lambda-\left(\lambda_{\mathrm{T}}+\lambda_{H}+\mu\right) S \\
& \frac{d E_{T}}{d t}=\lambda_{T}\left(S+R_{T}\right)-\left(\psi_{1} \lambda_{T}+k+\lambda_{H}+u_{1}+\mu\right) E_{T} \\
& \frac{d I_{T}}{d t}=\left(\psi_{1} \lambda_{T}+k\right) E_{T}+q R_{T}-\left(\delta \lambda_{H}+p+u_{2}+\mu+d_{T}\right) I_{T} \\
& \frac{d R_{T}}{d t}=u_{1} E_{T}+\left(p+u_{2}\right) I_{T}-\left(q+\lambda_{T}+\lambda_{H}+\mu\right) R_{T} \\
& \frac{d I_{H}}{d t}=\lambda_{H}\left(S+R_{T}\right)+u_{1} E_{T H}+u_{2} I_{T H}-\left(\lambda_{T}+\rho_{1}+u_{3}+\mu\right) I_{H} \\
& \frac{d I_{A}}{d t}=\rho_{1} I_{H}+u_{1} E_{T A}+u_{2} I_{T A}-\left(\sigma \lambda_{T}+\mu+d_{A}\right) I_{A} \\
& \frac{d E_{T H}}{d t}=\lambda_{H} E_{T}+\lambda_{T} I_{H}-\left(\psi_{2} \lambda_{T}+r_{1} k+\gamma_{1} \rho_{1}+u_{1}+u_{3}+\mu\right) E_{T H} \\
& \frac{d E_{T A}}{d t}=\gamma_{1} \rho_{1} E_{T H}+\sigma \lambda_{T} I_{A}-\left(\psi_{3} \lambda_{T}+r_{2} k+u_{1}+\mu+d_{A}\right) E_{T A} \\
& \frac{d I_{T H}}{d t}=\delta \lambda_{H} I_{T}+\left(\psi_{2} \lambda_{T}+r_{1} k\right) E_{T H}-\left(\gamma_{2} \rho_{1}+u_{2}+u_{3}+\mu+d_{T}\right) I_{T H} \\
& \frac{d I_{T A}}{d t}=\gamma_{2} \rho_{1} I_{T H}+\left(\psi_{3} \lambda_{T}+r_{2} k\right) E_{T A}-\left(u_{2}+\mu+d_{T}+\varepsilon d_{A}\right) I_{T A} \\
& \frac{d R_{H}}{d t}=u_{3}\left(I_{H}+E_{T H}+I_{T H}\right)-\mu R_{H}
\end{aligned}
$$

With the initial conditions provided:

$S(0)=S_{0}, E_{T}(0)=E_{T 0}, I_{T}(0)=I_{T 0}, R_{T}(0)=R_{T 0}, I_{H}(0)=I_{H 0}, I_{A}(0)=I_{A 0}, E_{T H}(0)=E_{T H 0}$, $E_{T A}(0)=E_{T A 0}, I_{T H}(0)=I_{T H 0}, I_{T A}(0)=I_{T A 0}, R_{H}(0)=R_{H 0}$, and unspecified for $S\left(t_{f}\right), E_{T}\left(t_{f}\right), I_{T}\left(t_{f}\right), R_{T}\left(t_{f}\right), I_{H}\left(t_{f}\right), I_{A}\left(t_{f}\right), E_{T H}\left(t_{f}\right), E_{T A}\left(t_{f}\right), I_{T H}\left(t_{f}\right), I_{T A}\left(t_{f}\right), R_{H}\left(t_{f}\right)$.

$\lambda_{T}=\frac{\beta_{T}}{N}\left(I_{T}+I_{T H}+I_{T A}\right)$

$\lambda_{H}=\frac{\beta_{H}}{N}\left(I_{H}+E_{T H}+I_{T H}+\eta_{A}\left(I_{A}+\eta_{T H}\left(\theta_{T H} I_{T A}+E_{T A}\right)\right)\right)$

where $N(t)=S(t)+E_{T}(t)+I_{T}(t)+R_{T}(t)+I_{H}(t)+I_{A}(t)+E_{T H}(t)+E_{T A}(t)+I_{T H}(t)+$ $I_{T A}(t)+R_{H}(t)$. 


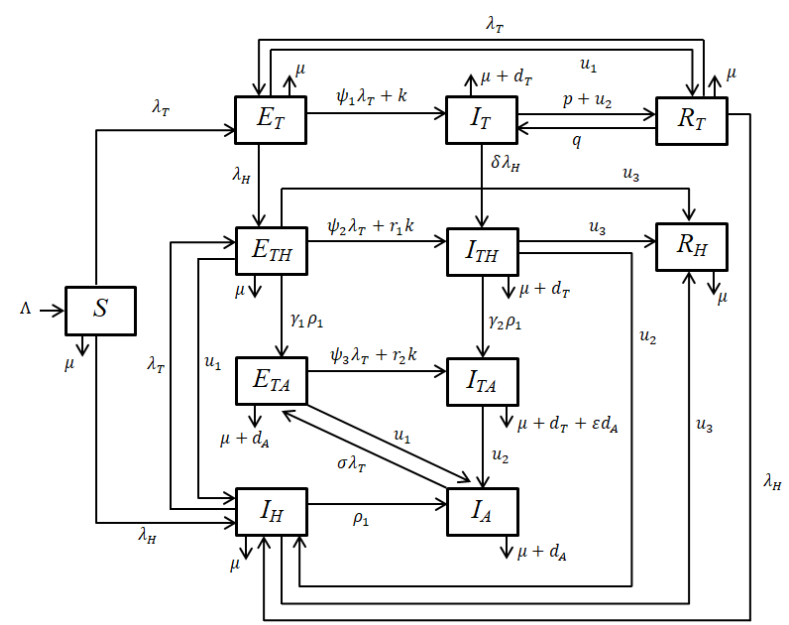

Figure 1. Modified compartment diagram of TB-HIV/AIDS coinfection spread

It is assumed that individuals born enter the susceptible class at the $\Lambda$ rate. Susceptible individuals can contract HIV due to direct contact with HIV infected individuals at the $\lambda_{H}$ rate thus enter into the HIV infected class. HIV in the body can develop into AIDS at the $\rho_{1}$ rate thus enter into the AIDS infected class. HIV and AIDS infected individuals can each contract TB due to direct contact with active TB individuals at the $\lambda_{T}$ and the $\sigma \lambda_{T}$ rate thus enter into the TB-HIV exposed and TB-AIDS exposed class. TB-HIV exposed individuals can progress their latent TB to the active TB naturally at the $r_{1} k$ rate and re-infection at the $\psi_{2} \lambda_{T}$ rate thus enter into the TB-HIV infected class. In addition, TB-HIV exposed individuals can progress their HIV into AIDS at the $\gamma_{1} \rho_{1}$ rate thus enter into the TB-AIDS exposed class. TB-AIDS exposed individuals can naturally progress their latent TB into active TB at the $r_{2} k$ rate and re-infection at the $\psi_{3} \lambda_{T}$ rate thus enter into the TB-AIDS infected class. TB-HIV infected individuals can progress their HIV into AIDS at the $\gamma_{2} \rho_{1}$ rate thus enter into the TB-AIDS infected class.

Susceptible individuals can contract TB due to direct contact with active TB individuals at the $\lambda_{T}$ rate thus enter into the TB exposed class. Individuals exposed with TB can become naturally active TB at the $k$ rate and re-infection at the $\psi_{1} \lambda_{T}$ rate thus enter into the TB infected class. Individuals infected with TB can recover naturally from the disease at the $p$ rate and enter into the recovered from TB class. Individuals exposed to TB and infected with TB can contract HIV due to direct contact with HIV infected individuals at the $\lambda_{H}$ rate and the $\delta \lambda_{H}$ rate thus enter into the TB-HIV exposed class and TB-HIV infected class, with $\delta>1$ being a modified parameter that describes active TB individuals as more susceptible to HIV compared to latent TB individuals.

Each population experiences death naturally at the $\mu$ rate. Individuals infected with TB can die from the disease at the $d_{T}$ rate. Individuals with AIDS can die from the disease at the $d_{A}$ rate. Individuals infected with TB-AIDS can die from the disease at the $\varepsilon d_{A}$ rate. The model is equipped with three treatments: the treatment of latent TB individuals using chemoprophylaxis at the $u_{1}$ rate, active TB individuals using several drugs at the $u_{2}$ rate and HIV individuals using ARV at the $u_{3}$ rate. HIV infected individuals who are given treatment enter into the HIV treatment class.

In Equation (3), $\beta_{H}$ is the rate of HIV infection, $\eta_{A} \geq 1$ describes individuals at the AIDS stage as more susceptible to transmitting HIV compared to individuals infected with HIV without showing symptoms of AIDS. $\eta_{T H} \geq 1$ is a modified parameter that describes transmission by individuals at the TB-AIDS exposed stage greater than individuals at the AIDS stage. Then for $\theta_{T H} \geq 1$ describes that individuals at the TBAIDS infected stage are easier to transmit HIV than at the TB-AIDS exposed stage. In Equation (2), $\beta_{T}$ is the rate of individuals exposed to TB due to direct contact with TB infected individuals and $c$ states the average contact rate. 


\section{Research Design}

\subsection{Solve optimal control problem}

If defined the control vector $\vec{u}(t)=\left(u_{1}(t), u_{2}(t), \ldots, u_{n}(t)\right)$ and state vector $\vec{x}(t)=\left(x_{1}(t), x_{2}(t), \ldots, x_{n}(t)\right)$ at the time interval $\left[t_{0}, t_{f}\right]$, the steps taken are: [26], [27]

a. Shape the Hamiltonian $H(x(t), u(t), m(t), t)=f(x(t), u(t), t)+m^{\prime}(t) g(x(t), u(t), t)$.

b. Minimize $H$ against all $u(t)$ using $\frac{\partial H}{\partial u}=0$, so get $u$ optimal $u^{*}(t)$.

c. Substitute $u^{*}(t)$ into $H$ to get optimal Hamiltonian $H^{*}$ function.

d. Solve equation of state with $\dot{x}^{*}=\frac{\partial H^{*}}{\partial m}$ and co-state with $\dot{m}^{*}=-\frac{\partial H^{*}}{\partial x}$. The boundary conditions are given by the initial and final condition (transverse) used is $m\left(t_{f}\right)=0$.

e. Substitute the result of step d. into the $u^{*}$ expression in step b. to get optimal control.

\subsection{Discretization and simulation}

$$
\begin{aligned}
x_{n+1}(t)= & x_{n}(t)+\frac{h}{6}\left(g\left(t_{n}, x_{n}, u_{n}\right)+2 g\left(t_{n}+\frac{h}{2}, x_{n}+\frac{h}{2} k_{1, x}, \frac{1}{2}\left(u_{n}+u_{n+1}\right)\right)+\right. \\
& \left.2 g\left(t_{n}+\frac{h}{2}, x_{n}+\frac{h}{2} k_{2, x}, \frac{1}{2}\left(u_{n}+u_{n+1}\right)\right)+g\left(t_{n}+h, x_{n}+h k_{3, x}, u_{n+1}\right)\right) \\
m_{n-1}(t)= & m_{n}(t)-\frac{h}{6}\left(p\left(t_{n}, x_{n}, u_{n}\right)+2 p\left(t_{n}-\frac{h}{2}, x_{n}-\frac{h}{2} k_{1, x}, \frac{1}{2}\left(u_{n}+u_{n-1}\right)\right)+\right. \\
& \left.2 p\left(t_{n}-\frac{h}{2}, x_{n}-\frac{h}{2} k_{2, x}, \frac{1}{2}\left(u_{n}+u_{n-1}\right)\right)+p\left(t_{n}-h, x_{n}-h k_{3, x}, u_{n-1}\right)\right)
\end{aligned}
$$

Discretization of the state as $\frac{d x(t)}{d t}=g(t, x(t), u(t))$ using forward sweep (4) and co-state as $\frac{d m(t)}{d t}=p(t, m(t), u(t))$ using backward sweep (5) with $\left[t_{0}, t_{f}\right]$. Then create a program to get a simulation with the following steps:[18], [22], [28], [29]

a. Divide the interval by $n$ subintervals, so that the vector state $\vec{x}=\left(x_{1}, x_{2}, \ldots, x_{n+1}\right)$, co-state $\vec{m}=\left(m_{1}, m_{2}, \ldots, m_{n+1}\right)$ and control $\vec{u}=\left(u_{1}, u_{2}, \ldots, u_{n+1}\right)$.

b. Use the initial value for $x\left(t_{0}\right)=a$ and the $u$ to finish the state with forward sweep.

c. Use the final value for $m\left(t_{f}\right)=0$ and the $x$ and $u$ values resulting from step $\mathrm{b}$. to complete the co-state with backward sweep.

d. Update the $u$ by subtituting the new $x$ and $m$ values in the $u^{*}(t)$ characterizations.

e. Performing convergence checks using $\delta_{c}|u|-\left|\sum_{i=1}^{n+1}\right| u-$ old $u|| \geq 0$.

Where $u$ is the new $u$, while old $u$ is the old $u$ value and $\delta_{c}$ is a constant of positive real value. If the value of each convergence test in the last iteration is positive, then the iteration stops and uses that value as the optimal value. But if not, then go back to step c.

\section{Result and Discussions}

\subsection{Optimal Control Problem}

Based on the purpose in this study, namely minimizing the spread of TB-HIV/AIDS coinfection, it will be minimized the number of populations of TB-HIV/AIDS coinfection either exposed to TB-HIV, exposed to TB-AIDS, infected with TB-HIV or infected with TB-AIDS. Therefore, objective function (6) was formed which means to minimize the number of TB-HIV/AIDS coinfection individuals with minimum medical expenses.

$$
J=\int_{t_{0}}^{t_{f}}\left(A_{1} E_{T H}+A_{2} E_{T A}+A_{3} I_{T H}+A_{4} I_{T A}+c_{1} u_{1}^{2}+c_{2} u_{2}^{2}+c_{3} u_{3}^{2}\right) d t
$$

Based on the objective function (6) and the function of constraints or state equations (1), the Hamiltonian function is obtained:

$$
H=A_{1} E_{T H}+A_{2} E_{T A}+A_{3} I_{T H}+A_{4} I_{T A}+c_{1} u_{1}^{2}+c_{2} u_{2}^{2}+c_{3} u_{3}^{2}+\sum_{i=1}^{11} m_{i} g_{i}
$$


Where $\mathrm{m}$ is the co-state and $\mathrm{g}$ is the state. Optimal control and co-state equations obtained:

a. Optimal conditions

$$
\begin{aligned}
& \frac{\partial H}{\partial u_{1}}=0 \text { retrieved } u_{1}^{*}=\min \left(1, \max \left(0, \frac{\left(m_{2}-m_{4}\right) E_{T}+\left(m_{7}-m_{5}\right) E_{T H}+\left(m_{8}-m_{6}\right) E_{T A}}{2 c_{1}}\right)\right) \\
& \frac{\partial H}{\partial u_{2}}=0 \text { retrieved } u_{2}^{*}=\min \left(1, \max \left(0, \frac{\left(m_{3}-m_{4}\right) I_{T}+\left(m_{9}-m_{5}\right) I_{T H}+\left(m_{10}-m_{6}\right) I_{T A}}{2 c_{2}}\right)\right) \\
& \frac{\partial H}{\partial u_{3}}=0 \text { retrieved } u_{3}^{*}=\min \left(1, \max \left(0, \frac{\left(m_{5}-m_{11}\right) I_{H}+\left(m_{7}-m_{11}\right) E_{T H}+\left(m_{9}-m_{11}\right) I_{T H}}{2 c_{3}}\right)\right)
\end{aligned}
$$

b. Adjoin/co-state

The acquisition of adjoin equations is $\dot{m}_{\iota}=-\frac{\partial H}{\partial x_{i}}$, where $x=\left[S, E_{T}, I_{T}, R_{T}, I_{H}, I_{A}\right.$, $\left.E_{T H}, E_{T A}, I_{T H}, I_{T A}, R_{H}\right]$ and final conditions $m_{i}\left(t_{f}\right)=0$ for $i=[1,11]$.

\subsection{Numerical Simulations}

The data used include the values of the initial conditions as $S_{0}=9080, E_{T 0}=2080$, $I_{T 0}=3540, R_{T 0}=0, I_{H 0}=1500, I_{A 0}=420, E_{T H 0}=1095, E_{T A 0}=325, I_{T H 0}=137, I_{T A 0}=$ $29, R_{H 0}=10$ and the parameters shown in Table 1 with $\left[t_{0}, t_{f}\right]=[0,10], A_{1}, A_{2}, A_{3}$, $A_{4}=1$ and $c_{1}, c_{2}$, and $c_{3}$ are worth 50, 80, and 100 [13], [21], [22], [30]. 7 scenarios trial shown in Table 2 will be used to obtain the best strategy in minimizing the spread of TBHIV/AIDS coinfection.

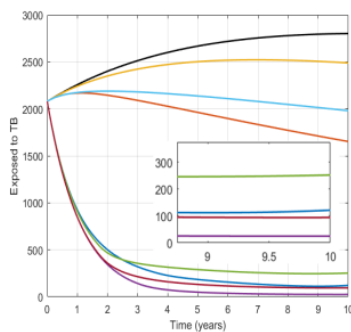

(a)

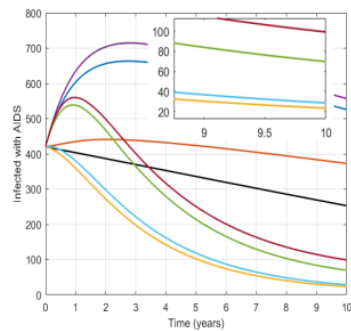

(e)

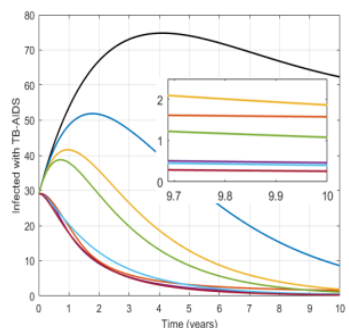

(i)

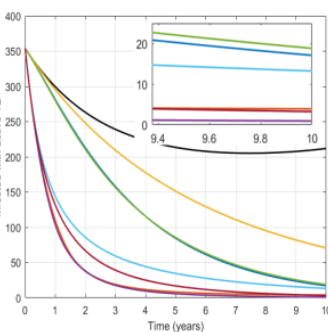

(b)

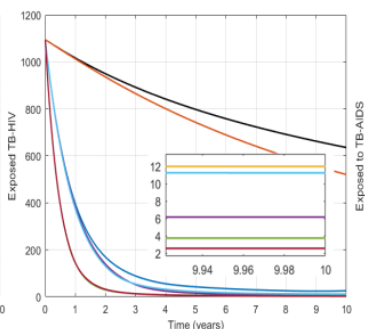

(f)

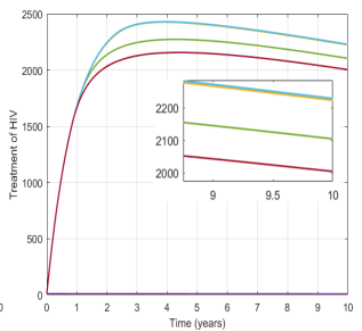

(j)

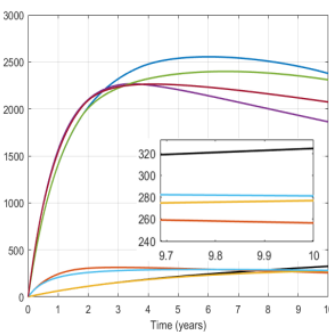

(c)

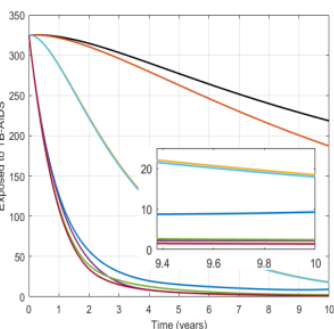

(g)

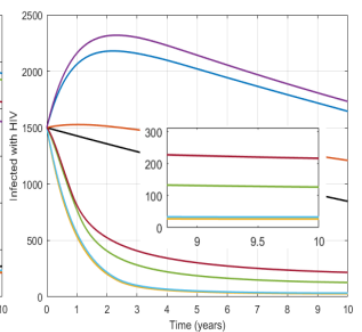

(d)

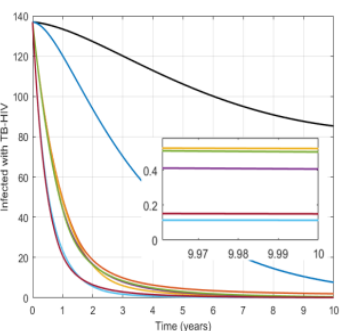

(h)

Figure 2. Population of (a) exposed to TB, (b) infected with TB, (c) recovered from TB, (d) infected with HIV, (e) infected with AIDS, (f) exposed to TB-HIV, (g) exposed to TBAIDS, (h) infected with TB-HIV, (i) infected with TB-AIDS and (j) treatment of HIV. 
Table 1. Parameters values

\begin{tabular}{ccc}
\hline No. & Parameters & Value \\
\hline 1. & $\Lambda$ & 0,029 \\
2. & $\mu$ & 0,02 \\
3. & $c$ & 3 \\
4. & $\theta_{T H}$ & 1,1 \\
5. & $\eta_{T H}$ & 1,05 \\
6. & $\eta_{A}$ & 1,02 \\
7. & $\rho_{1}$ & 0,1 \\
8. & $\gamma_{1} \rho_{1}$ & 0,102 \\
9. & $\gamma_{2} \rho_{1}$ & 0,25 \\
10. & $\delta$ & 1,03 \\
11. & $\varepsilon$ & 1,2 \\
12. & $\sigma$ & 1,2 \\
13. & $k$ & 0,000113 \\
14. & $r_{1} k$ & 0,00017 \\
15. & $r_{2} k$ & 0,0002 \\
16. & $\psi_{1}$ & 0,71 \\
17. & $\psi_{2}$ & 1,07 \\
18. & $\psi_{3}$ & 1,101 \\
19. & $d_{T}$ & 0,1 \\
20. & $d_{A}$ & 0,333 \\
21. & $\beta_{T}$ & 0,35 \\
22. & $\beta_{H}$ & 0,15 \\
23. & $p$ & 0,2 \\
24. & $q$ & 0,0001 \\
\hline
\end{tabular}

The simulation results obtained for the TB-HIV/AIDS coinfection populations include, Figure 2 (f) shows the exposed to TB-HIV population without and with treatment. The figure shows that each scenario graph is lower than the no-control graph, this shows that treatment in each scenario may result in a reduced the number of TB-HIV exposed individuals. The scenario that results in the least number of TB-HIV exposed individuals is scenario 7 whereby by administering treatment for individuals with latent TB, active TB and HIV can reduce the population of exposed to TB-HIV to 3 people. Figure $2(\mathrm{~g})$ shows the exposed to TB-AIDS population without and with treatment. Treatment in each scenario resulted in the number of TB-AIDS exposed individuals being reduced as shown in each scenario graph decreased compared to the no-control graph. The scenario that results in the least number of TB-AIDS exposed individuals is scenario 7 whereby by administering treatment for individuals with latent TB, active TB and HIV can reduce the population of TB-AIDS exposed to 1 people. Figure 2 (h) shows the infected with TB-HIV population without and with treatment. The figure shows that each scenario graph is lower than the no-control graph, this shows that treatment in each scenario may result in a reduced the number of TB-HIV infected individuals. The best scenario for reducing the population of infected with TB-HIV is scenario 6 whereby by administering treatment for individuals with active TB and HIV can eliminate the TBHIV infected population. Figure 2 (i) shows the infected with TB-AIDS population without and with treatment. Treatment in each scenario resulted in the number of TBAIDS infected individuals being reduced as shown in each scenario graph decreased compared to the no-control graph. The best scenario for reducing the population of infected with TB-AIDS is scenario 7 whereby by administering treatment for individuals with latent TB, active TB and HIV can eliminate the TB-AIDS infected population.

The simulation results obtained for the TB populations include, Figure 2 (a) shows the exposed to TB population without and with treatment. The figure shows that each scenario graph is lower than the no-control graph, this shows that treatment in each 
scenario may result in a reduced the number of TB exposed individuals. The scenario that results in the least number of TB exposed individuals is scenario 4 whereby by administering treatment for individuals with latent $\mathrm{TB}$ and active $\mathrm{TB}$ can reduce the population of TB exposed to 25 people. Figure 2 (b) shows the infected with active TB population without and with treatment. Treatment in each scenario resulted in the number of active TB individuals being reduced as shown in each scenario graph decreased compared to the no-control graph. The scenario that results in the least number of active TB individuals is scenario 4 whereby by administering treatment for individuals with latent TB and active TB can reduce the population of active TB to 1 people. Figure 2 (c) shows the recovered from TB population without and with treatment. Scenario graphs 1, 4, 5 and 7 experienced an increase compared to the no-control graph, this shows that giving treatment in these four scenarios can result in the number of recovered from TB individuals increased compared to without treatment. While the scenario graphs 2, 3 and 6 experienced an decrease compared to the no-control graph. This can happen because in these three scenarios TB treatment is done only for active TB individuals without treatment for latent TB individuals, so the recovered from TB class will only get additions from active TB individuals who are cured due to $u_{2}$. Therefore, the scenario graphs 2,3 and 6 in the TB exposed population are higher than the other four scenarios that provide treatment for TB exposed individuals as shown in Figure 2 (a). The scenario that results in the largest number of recovered from TB individuals is scenario 1 whereby by treating individuals with latent TB can result in as many as 2377 people recovered from TB.

The simulation results obtained for the HIV/AIDS populations include, Figure 2 (d) shows the infected with HIV population without and with treatment. Scenario graphs 3, 5, 6 and 7 decrease compared to the no-control graph, this shows that giving treatment in these four scenarios can result in a reduced number of HIV infected individuals compared to without treatment. This can happen because each of these four scenarios is given treatment for HIV infected individuals using ARV, resulted in HIV treatment class with ARV increased in these four scenarios. Meanwhile, scenario graphs 1, 2 and 4 increased compared to the no-control graph. This indicates that the number of HIV infected individuals in scenarios 1,2 and 4 increases compared to the absence of treatment that occurs because in these three scenarios there is no treatment for HIV infected individuals. The scenario that results in the least number of HIV infected individuals is scenario 3 whereby by administering treatment for individuals with HIV infected can reduce the population of infected with HIV to 27 people. Figure 2 (e) shows the affected with AIDS population without and with treatment. Scenario graphs 3, 5, 6 and 7 are lower than the no-control graph. This is related to the previous discussion, in which in these four scenarios experienced a decrease in the number of HIV infected individuals which resulted in a decrease in the population of individuals with AIDS. While in the scenario graphs 1, 2 and 4 are higher than the no-control graph. This can happen because of the increasing HIV infected population, resulting in an increase in the AIDS population. The scenario that results in the least number of individuals affected with AIDS is scenario 3 whereby by administering treatment for individuals with HIV infected can reduce the population of infected with AIDS to 23 people. Figure 2 (j) shows the HIV treatment population without and with treatment. Scenario graphs 3, 5, 6 and 7 are higher than the no-control graph. This can happen because each of these four scenarios, treatment for people with HIV is carried out, causing the number of individuals in the HIV treatment class to increase. While the scenario graphs 1,2 and 4 did not experience differences with no-control graph because in these three scenarios no treatment was given to people with HIV. The scenario that results in the largest number of individuals on HIV treatment is scenario 6 whereby by administering treatment for individuals with active TB and HIV infected can increase the number of individuals in HIV treatment to 2229 people. 


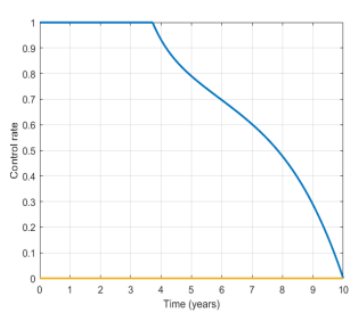

(a)

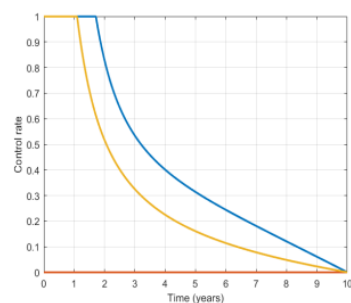

(e)

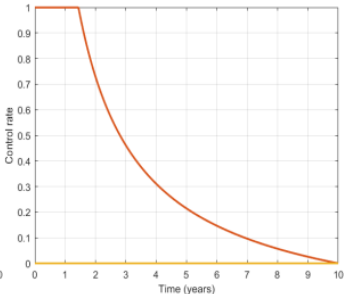

(b)

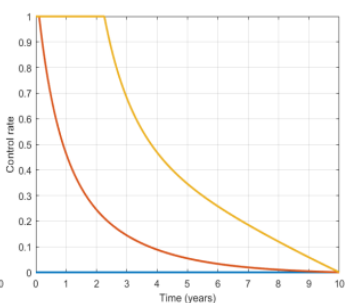

(f)

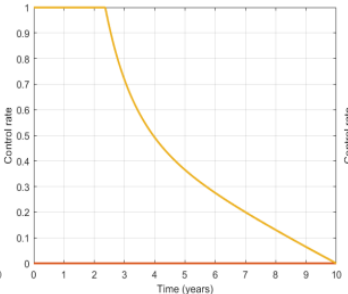

(c)

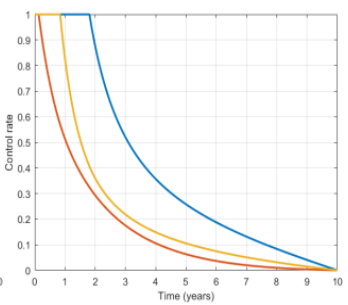

(g)

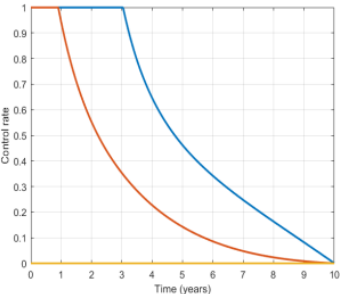

(d)

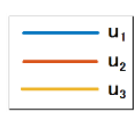

Figure 3. Change control on (a) scenario 1, (b) scenario 2, (c) scenario 3, (d) scenario 4, (e) scenario 5, (f) scenario 6 and (g) scenario 7

Table 2 shows the results of the objective function (6). The scenario with the largest objective function value is generated by scenario 2 with 10697,09 while the smallest objective function value is generated by scenario 7 with 1401,44 . The control graphs $u_{1}$, $u_{2}$ and $u_{3}$ in each scenario decrease as shown in Figure 3. This can happen because the number of sufferers decreases over time, causing the rate of treatments also to decrease.

Table 2. Scenario trial and objective function results

\begin{tabular}{ccc}
\hline Scenario & Description & Objective function $\boldsymbol{J}$ \\
\hline 1 & $u_{1}$ on & 2910,31 \\
2 & $u_{2}$ on & 10697,09 \\
3 & $u_{3}$ on & 3027,08 \\
4 & $u_{1}, u_{2}$ on & 2017,46 \\
5 & $u_{1}, u_{3}$ on & 1559,21 \\
6 & $u_{2}, u_{3}$ on & 2893,22 \\
7 & $u_{1}, u_{2}, u_{3}$ on & 1401,44 \\
\hline
\end{tabular}

Table 3 shows the final results of each population in the modified model showing a better value than the previous model. The final number of people with disease decreased more when using the modified model than using the previous model. This shows that using the modified model can further reduce the number of TB-HIV/AIDS coinfected patiens.

Table 3. Comparison of the best scenario results

\begin{tabular}{|c|c|c|c|}
\hline \multirow{3}{*}{ Class } & \multicolumn{3}{|c|}{ Population } \\
\hline & \multirow{2}{*}{ Initial } & \multicolumn{2}{|c|}{ Final } \\
\hline & & Previous model & Modified model \\
\hline$E_{T}$ & 2080 & 1785 & 94 \\
\hline$I_{T}$ & 354 & 57 & 3 \\
\hline$R_{T}$ & 0 & 899 & 2073 \\
\hline$I_{H}$ & 1500 & 1205 & 217 \\
\hline$I_{A}$ & 420 & 375 & 99 \\
\hline$E_{T H}$ & 1095 & 428 & 3 \\
\hline$E_{T A}$ & 325 & 149 & 1 \\
\hline$I_{T H}$ & 137 & 24 & 0 \\
\hline$I_{T A}$ & 29 & 20 & 0 \\
\hline
\end{tabular}




\section{Conclusion}

After obtained the results as described above, it can be concluded that in this study the best scenario is a scenario that desires the smallest objective function value of $J$ to control the spread of TB-HIV/AIDS coinfection with the modified model is scenario 7 namely the use of $u_{1}, u_{2}$, and $u_{3}$. This indicates that by treating individuals with latent TB, active TB, and HIV infected in tandem, it will reduce the populations of TBHIV/AIDS coinfection more quickly with smaller treatment costs.

For further research can use the original and up-to-date data to see the realization of the modified model. Then, can try using Runge-Kutta method with a higher order. And can add new controls in the form of the use of contraceptives such as condoms during sexual intercourse, thus forming a new model that may be more effective.

\section{References}

[1] W. Sukokarlinda, "Analisis dan kontrol optimal pada model penyebaran virus HIV dalam tubuh manusia," Skripsi, 2012.

[2] UNAIDS, "Fact sheet - Global AIDS update 2019," UNAIDS, pp. 1-6, 2019.

[3] UNAIDS, “Country Indonesia," UNAIDS, 2019. [Online]. Available: https://www.unaids.org/en/regionscountries/countries/indonesia. [Accessed: 25Sep-2019].

[4] A. H. M. Zeth, A. H. Asdie, A. G. Mukti, and J. Mansoden, "Perilaku dan risiko penyakit HIV-AIDS di masyarakat papua studi pengembangan model lokal kebijakan HIV-AIDS," J. Manaj. Pelayanan Kesehat., vol. 13, no. 4, pp. 206-219, 2010.

[5] S. Murni, C. W. Green, S. Djauzi, A. Setiyanto, and S. Okta, Hidup dengan HIV/AIDS. Jakarta: Spiritia, 2009.

[6] A. Khan, J. F. G. Aguilar, T. S. Khan, and H. Khan, "Stability analysis and numerical solutions of fractional order HIV/AIDS model," Chaos, Solitons and Fractals, vol. 122, pp. 119-128, 2019.

[7] A. Rusli, "Koinfeksi HIV \& TB," 2014.

[8] WHO, Global Tuberculosis report. WHO (World Health Organization), 2018.

[9] CDC, "Latent TB infection and TB disease," 2016. [Online]. Available: https://www.cdc.gov/tb/topic/basics/tbinfectiondisease.htm. [Accessed: 19-Sep2019].

[10] Setiawan, "Kontrol optimal penyebaran tuberkulosis dengan exogenous reinfection," Indonesia University, 2012.

[11] I. Marlina, Tuberkulosis, vol. 2, no. 1. Jakarta: Kemenkes RI, 2018.

[12] J. Nainggolan, "Kontrol pengobatan optimal pada model penyebaran Tuberkulosis tipe SEIT," E-Jurnal Mat., vol. 6, no. 2, p. 137, 2017.

[13] S. N. Rayhan, "Kontrol optimum penyebaran koinfeksi penyakit tuberkulosis dan HIV/AIDS,” Intitut Pertanian Bogor (IPB), 2017.

[14] CDC, Core Curriculum on Tuberculosis, Sixth Edit. (CDC) Centers for Disease Control and Prevention, 2013.

[15] E. Michael and R. C. Spear, Modelling parasite transmission and control. New York, USA: Springer Science \& Business Media, 2010. 
[16] WHO, The health academy avoiding Tuberculosis. Switzerland: Geneva, 2004.

[17] Bolarin and Omatola, "A mathematical analysis of HIV/TB co-infection model," Appl. Math., vol. 6, no. 4, pp. 65-72, 2006.

[18] G. R. Rose, Numerical methods for solving optimal control problems. University of Tennessee, 2015.

[19] E. R. Hidayah, "Kontrol optimal model pertumbuhan tumor dengan imunoterapi," Skripsi, 2016.

[20] D. peng Gao and N. jing Huang, "Optimal control analysis of a Tuberculosis model," Appl. Math. Model., vol. 58, pp. 47-64, 2018.

[21] C. . Bhunu, W. Garira, and Z. Mukandavire, "Modelling HIV/AIDS and Tuberculosis coinfection," Bull. Math. Biol., vol. 71, pp. 1745-1780, 2009.

[22] Tanvi and R. Aggarwal, "Dynamics of HIV-TB co-infection with detection as optimal intervention strategy," Int. J. Non-Linear Machanics, vol. 516, pp. 280307, 2019.

[23] Huzaimah, "Metode analitik dan metode Runge-Kutta orde 4 dalam penyelesaian persamaan getaran pegas teredam," Universitas Islam Negeri Maulana Malik Ibrahim, Malang, 2016.

[24] Subhashini and Srividhya, "Comparison of several numerical algorithms with the use of predictor and corrector for solving ODE," Int. J. Trend Sci. Res. Dev., vol. 3, pp. 1057-1060, 2019.

[25] Puspitasari, Intan, A. Sutrisno, T. Ruby, and M. Ansori, "Pembandingan metode Runge-Kutta orde 4 dan Metode Adam-Bashfort Moulton dalam penyelesaian model pertumbuhan uang yang diinvestasikan," in Prosiding Seminar Nasional Metode Kuantitatif 2017, 2010, pp. 328-340.

[26] A. Chiang, Fundamental method of mathematical economics fourth edition. New York: The McGraw-Hill, 2005.

[27] D. S. Naidu, Optimal control systems. New York: CRC Press, 2002.

[28] F. Puspitasari, "Masalah kontrol optimal pada model penyebaran penyakit demam berdarah dengan pengaruh musim," Institut Teknologi Bandung, 2017.

[29] S. A. Hardiyanti, "Kontrol optimal sistem perawatan produksi dengan memperhatikan kerusakan produk dan tingkat diskon," Institut Teknologi Sepuluh Nopember, Surabaya, 2016.

[30] Fatmawati and H. Tasman, "An optimal treatment control of TB-HIV coinfection," Int. J. Math. Math. Sci., 2016. 